\title{
Long-term sustainability of cork oak agro-forests in the Iberian Peninsula: A model-based approach aimed at supporting the best management options for the montado conservation
}

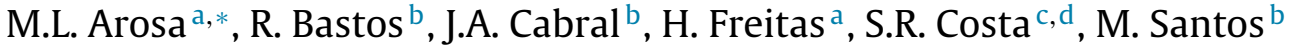 \\ a Centre for Functional Ecology, Department of Life Sciences, University of Coimbra, P.O. Box 3046, 3001-401 Coimbra, Portugal \\ ${ }^{\mathrm{b}}$ Laboratory of Applied Ecology, CITAB - Centre for the Research and Technology of Agro-Environment and Biological Sciences, University of \\ Trás-os-Montes e Alto Douro, 5000-911 Vila Real, Portugal \\ ' Mountain Research Center (CIMO), ESA, Polytechnic Institute of Bragança, Campus de Santa Apolónia, 5300-253 Bragança, Portugal \\ d CBMA - Centre of Molecular and Environmental Biology, Department of Biology, University of Minho, Campus de Gualtar, 4710-057 Braga, Portugal
}

\section{A R T I C L E I N F O}

\section{Article history:}

Received 25 March 2016

Received in revised form

26 September 2016

Accepted 10 October 2016

Available online 31 October 2016

\section{Keywords:}

Quercus suber

Modelling

Montado sustainability

Population dynamics

\begin{abstract}
A B S T R A C T
The future of the montado, a human shaped agro-forestry ecosystem of South Western Europe, is questioned due to the observed lack of cork oak health and low natural regeneration. We developed a System Dynamics Modelling approach to predict the long-term sustainability of this agro-forest, by recreating cork-oak population dynamics, management practices and the main environmental and biological constrains associated with this ecosystem. Our results indicate that the leading limitations to cork oak regeneration in montado ecosystems result from the intensity and interaction of land management practices, namely livestock and the use of heavy machinery. The main conclusions indicate that limiting the quantity of livestock up to 0.40 LU.ha $^{-1}$, and considering soil ploughing with a minimum periodicity of 5 years, are crucial to maintaining sustainable cork oak populations. This study represents a first step to support strategic options for cork oak montado management by providing projections of long-term population trends under realistic social-ecological change scenarios.
\end{abstract}

(C) 2016 Elsevier B.V. All rights reserved.

\section{Introduction}

The largest cork oak woodlands are found in the Iberian Peninsula, where cork harvesting, agricultural, pastoral and other traditional uses have been practiced at least since the Middle Ages (Joffre et al., 1999; Olea et al., 2005; Bugalho et al., 2011). This agro-silvo-pastoral ecosystem, known as montado or dehesa (the Portuguese and Spanish names, respectively), is composed typically of open woodlands (20-80 trees ha ${ }^{-1}$ ) with only one or a few tree species such as cork oak (Quercus suber), holm oak (Quercus rotundifolia) and pines (Pinus spp.) (Joffre et al., 1999; Pinto-Correia and Mascarenhas, 1999; Pinto-Correia and Fonseca, 2009). Moreover, the montado ecosystem is considered both a protected habitat within the EU habitats directive (92/43/EEC) and a high nature value farming system, according to the classification proposed by the European Environmental Agency (Paracchini et al., 2008).

\footnotetext{
* Corresponding author.

E-mail address: merisinha@hotmail.com (M.L. Arosa).
}

The dominant tree of the montado, the cork oak (Quercus suber), is a sclerophyllous evergreen oak that occurs in non-carbonated soils (Pausas et al., 2009) restricted to the western part of the Mediterranean Basin (Tutin et al., 1964). This is a slow-growing tree with a high longevity like other oaks, with a lifespan of 250-300 years. Earliest flowering and fructification occur at around 15-20 years of age, producing both annual and biennial acorns (Natividade, 1950; Elena-Rosselló et al., 1993; Díaz-Fernández et al., 2004; Pereira and Tomé, 2004). Acorns can be dispersed by animals or predated. The main seed dispersers are wood mouse (Apodemus sylvaticus) and European jay (Garrulus glandarius), which are involved in short- and long-distance dispersal, respectively (Herrera, 1995; Pausas et al., 2009). Acorn predators are mainly seed-boring insects, such as the acorn weevil (Curculio spp., Coleoptera) and the acorn moth (Cydia spp., Lepidoptera) (Ceia and Ramos, 2014). In open areas, predators can also be livestock, deer, wild boar, birds and rabbits whereas under a shrub canopy acorn predation is mostly carried out by small rodents, since neither large mammals nor birds will penetrate the dense vegetation (Herrera, 1995). Cork oak trees grow in areas with strong seasonal water deficits by surviving to droughts in part due to their 


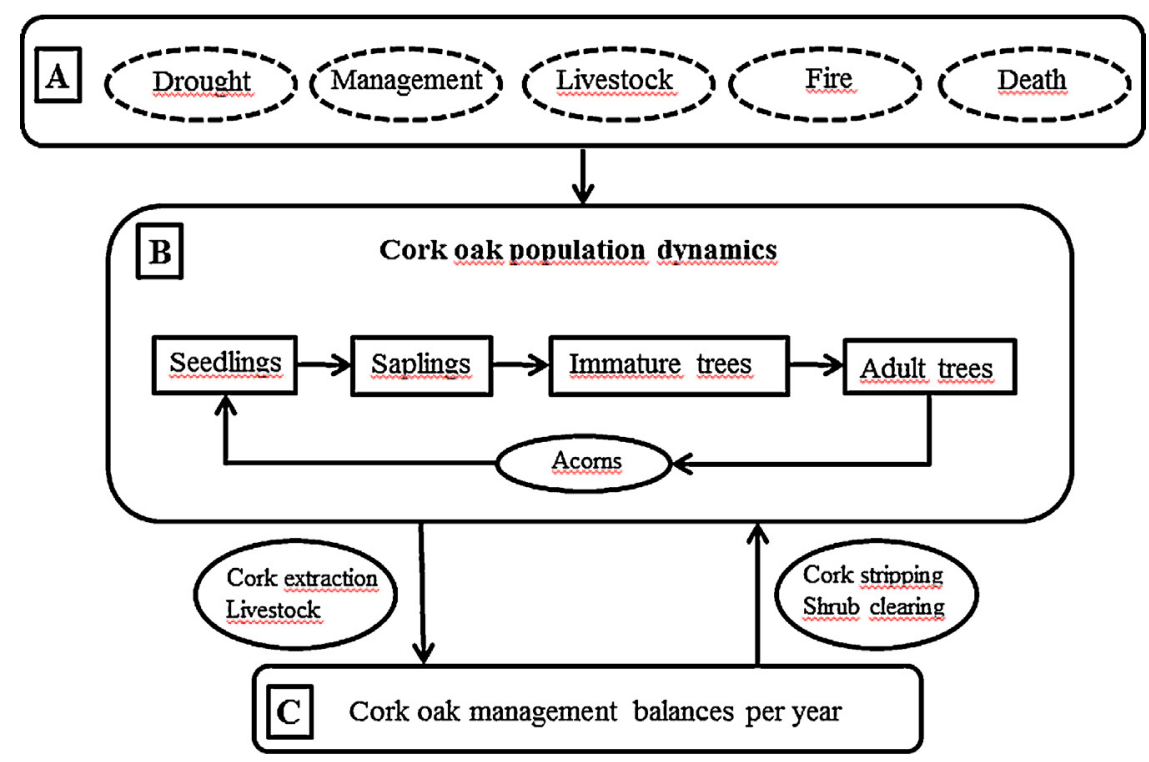

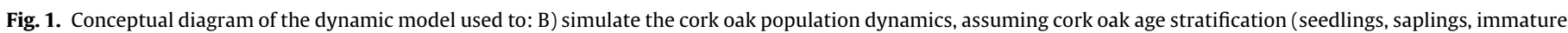
trees and adult trees), A) simulate the associated environmental constrains and C) the respective economic balance sub-model.

extensive and deep root system and in some cases seedlings shed leaves and resprout when the drought is over (Acácio et al., 2007; Gómez-Aparicio et al., 2008; Arosa et al., 2015). The cork oak has a thick insulating bark which evolved as a fire protection mechanism (Pausas, 1997; Catry et al., 2012) and which regrows after extraction for cork production (Pausas et al., 2009). Cork extraction represents an important resource of high economic value in the Iberian Peninsula as cork thickness and properties make it valuable raw material for industry. After the removal of the outer bark, a traditional practice that does not harm the tree and occurs every 9 years, the tree has the capacity to produce a new cork bark by adding new layers of cork every year and this may be repeated throughout the tree lifetime (Pausas et al., 2009). The annual production of cork is about $370000 \mathrm{t}$, mostly from the cork oaks of Portugal and Spain that produce respectively $51 \%$ and $23 \%$ of the world total (Pereira and Tomé, 2004).

Our main goal was the integration of disperse information from specific studies concerning the different life stages and stressors in a single user-friendly platform for understanding and predicting the future sustainability of the montado ecosystem. We considered as stressors the lack of cork oak health and the low natural regeneration rates. Tree health has been affected by intensive pruning, exaggerated cork harvesting and the influence of pests and diseases (Camilo-Alves et al., 2013; Acácio and Holmgren, 2014). The limitations to natural regeneration have been attributed to various causes, including: a) poor dispersal and shortage of viable acorns (Branco et al., 2002; Pulido and Díaz, 2005; Acácio et al., 2007); b) high post-dispersive acorn losses associated with seedling mortality due to over-grazing by livestock and wild animals (Herrera, 1995; Plieninger et al., 2004; Acácio et al., 2007; Pulido et al., 2013); c) low seedling survival to summer drought (Gimeno et al., 2009; Smit et al., 2009). Besides, the development of farm mechanization, including the generalised use of wide plows, disc harrows, and scarifiers destroys young trees and may damage roots and weaken established trees, creating more susceptibility to the attack of pests and diseases (Branco and Ramos, 2009; Arosa et al., 2015). The fire frequency detected in the last few decades in this ecosystem (Pausas and Vallejo, 1999) has also become an additional obstacle to cork oak survival and recruitment (Acácio et al., 2009, 2010). Although cork oak is able to exhibit fire-resistance characteristics due to the bark insulation and to the mechanism of resprout- ing afterwards, frequent or intense wildfires may kill adult trees, especially if these events occur immediately after cork extraction (Moreira et al., 2007). Additionally, as consequence of concomitant change of mean annual temperature and rainfall extremes during the last decades, the recurrent droughts will reduce the canopy cover and limit cork oak regeneration (Vivas and Maia, 2008; Acácio et al., 2009).

Considering its ecological and economic sustainability, the conservation of these ecosystems requires the comprehension of its capacity to withstand and recover from disturbances imposed by natural and anthropogenic factors (Müller, 2005; Kandziora et al., 2013; Stoll et al., 2015). Ecological modelling provides useful tools to study complex systems by predicting the outcome of alternative scenarios, and might help guiding the most correct management options from projected future outcomes (e.g. Bastos et al., 2012, 2015; Fernandes et al., 2013; Santos et al., 2013). Actually dynamic models can be used to support the mechanistic understanding of complex multifactorial ecological processes as they simultaneously integrate the structure and the composition of systems for a specific period (Jørgensen, 1994, 2001). When properly developed, tested and applied with insight and with respect for their underlying assumptions, dynamic models are capable of simulating conditions that are difficult or impossible to produce otherwise (Jørgensen, 2001).

We have developed a System Dynamics Modelling approach to recreate the management practices associated with cork oak montado and the main biological and environmental drivers influencing this semi-natural ecosystem, in order to assess its long-term sustainability (Sterman, 2001). This study is the first to integrate in a single approach the multifactorial factors associated with cork oak population dynamics. Specifically, our objectives were: (1) integrating in a user-friendly platform the biotic and abiotic factors, acting as a whole, with holistic and interrelated influences on the cork oak population dynamics (2) simulate realistic scenarios in order to understand the most determinant factors implicated in the cork oak decline across the Iberian Peninsula and (3) highlight the most effective management practices through quantitative metrics with implications for the long-term sustainability and conservation of the montado ecosystem. 


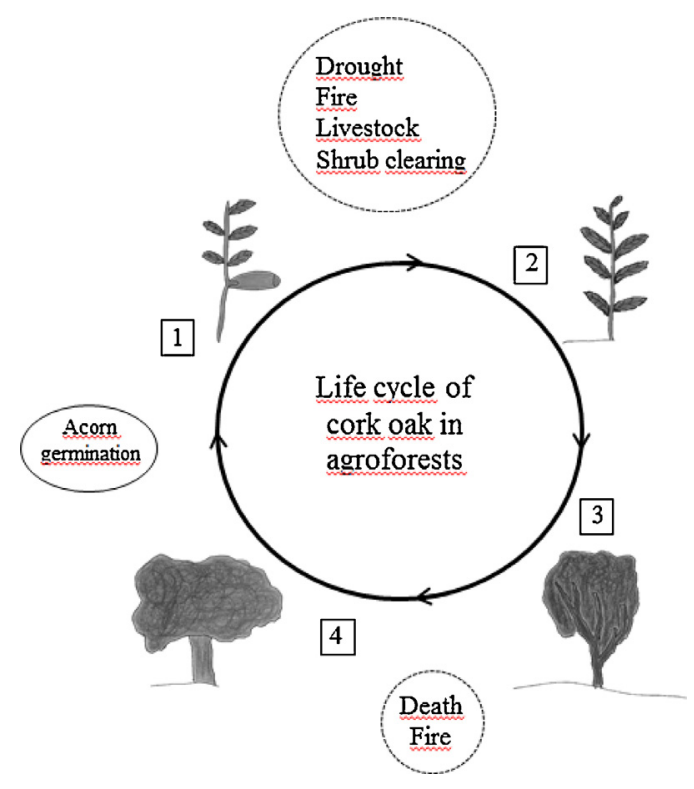

Fig. 2. Classes in the life cycle of cork oak in agroforests considered for the design of the conceptual diagram of the four sub-models: 1 seedlings, 2 saplings, 3 immature trees, 4 adult trees and the processes influencing each cohort of individuals. Drought, fire, livestock and shrub clearing are processes that most affect 1 and 2 classes. Death and fire have an important effect over 3 and 4 classes. Individuals of a specific class transit to the next when completing their development.

\section{Methods}

\subsection{Dynamic model conceptualization}

Cork oak population dynamics in agro-forests were modelled to anticipate the potential effects of current management practices under different environmental scenarios expected for the $21 \mathrm{st}$ century. Natural regeneration is a dynamic process where new individuals are recruited into the mature population, compensating the losses due to mortality, induced by several biotic and abiotic factors (Harper, 1977; Holmgren et al., 1997; Pulido and Díaz, 2005; Fei and Steiner, 2008). Therefore, we developed a System Dynamics Modelling approach composed by four sub-models concerning the cork oak population dynamics based on cork oak age stratification (classes) (González et al., 2015), represented by the sum of different life stage cohorts (seedlings, saplings, immature trees and adult trees), and one additional sub-model to estimate the economic balances associated (Fig. 1).

The year was chosen as time unit and the simulation period was established for 100 years, considered suitable to capture the influence of main factors on the long term cork oak population dynamics, namely those induced by management options. All modelling was performed with the software STELLA, version 10.0.5 (Isee Systems, Inc.). The original conceptual diagram of the overall sub-models (Appendix I in Supplementary material), variables and equations included in the model construction (Table 1 and Appendix II in Supplementary material) and full explanation of processes (Appendix III in Supplementary material), are available as supplementary electronic material.

\section{Natural regeneration}

In order to recreate cork oak natural regeneration, four submodels (seedlings, saplings, immature trees, adult trees) were designed to reproduce the most relevant classes, dynamics and environmental constrains associated to the cork oak populations (Fig. 1, Table 1, Appendix I, Appendix II in Supplementary material, Fig. 3). For each sub-model, cork oak trees were grouped into classes, considering their stage, size and diameter at breast height (DBH): seedlings (acorn or cotyledon scatters still attached, height $<50 \mathrm{~cm}$ ), saplings (height $>50 \mathrm{~cm}, \mathrm{DBH}<10 \mathrm{~cm}$ ), immature tree (height $>50 \mathrm{~cm}, \mathrm{DBH}>10 \mathrm{~cm}$ ) and adult tree $(\mathrm{DBH}>25 \mathrm{~cm}$ ) (Muick and Bartolome, 1987; Montero and Cañellas, 2003). Transitions between classes and within each class were affected by biotic and abiotic factors that implicate cause-effect relationships. Data used in the model was compiled from publications regarding the cork oak' life cycle and the cork oak montado characterization in the Iberian Peninsula, ranging from inland regions, with lower annual precipitation $(550 \mathrm{~mm})$ and higher temperature $\left(17^{\circ} \mathrm{C}\right)$, to coastal regions, with higher rainfall $(1800 \mathrm{~mm})$ and milder temperatures $\left(14^{\circ} \mathrm{C}\right)$ (Table 1$)$.

\subsection{Biotic and abiotic processes influencing cork oak natural regeneration}

Several biotic and abiotic processes were assumed as influent drivers on the cork oak population dynamics. The seedlings and saplings were mainly affected by droughts, fire effects, livestock and grazing pressure, and shrub clearing intensity (Fig. 2). On the other hand, immature and adult trees were affected by fire and natural death by aging. Besides the effect of external factors, the transition of individuals throughout classes considered into the model is also limited by intraspecific competition and by the success of established cork oak plants.

\subsubsection{Acorn germination}

To model the germination of acorns, each adult tree was assumed to produce between 1.32 and $33.6 \mathrm{~kg}$ of acorns per year (Herrera, 1995; Cañellas et al., 2007; Pérez-Ramos et al., 2008). Since the germination of acorns is limited by biotic factors related with predation and insect damages, the effective number of acorns supplying the system was dependent on the predation/survival rate and of the proportion of viable acorns (Branco et al., 2002; Acacio et al., 2007). Furthermore, acorns that do not germinate and remain in the understory dry out and become inviable before the beginning of a new year.

\subsubsection{Competition}

Cork oak competition in montado involves an intraspecific struggle for basic resources, such as light, water and/or nutrients (Flores-Martinez et al., 1994; Holmgren et al., 1997; Callaway and Walker, 1997). Our dynamic model was designed to recreate intraspecific competition within and between the different classes, from the sapling to the adult trees. During the tree development, competition varies from soil resources to light, this last affecting the shape and size of crowns (Kenkel, 1988; Deleuze et al., 1996). With increasing tree cover and light limitation, the older individuals begin to disproportionately obstruct the incoming solar radiation because of its unidirectional nature, thereby suppressing the growth of younger trees (Dolezal et al., 2004). In this context, Assmann and Gardiner (1970) defined that the area available for a tree is represented by its crown projection versus the corresponding fraction not occupied. Serrada (2002) estimated that this method suffers the disadvantage of supposing a full canopy cover (100\%) but in cork oak montados the normal canopy cover is incomplete, thus we used the Di Bérengerís method for calculating average crown projection using the diameter at breast height (DBH). This method enables the calculation of tree distribution within an area, assuming a mixture of trees belonging to all classes. Through the function $\mathrm{y}=0.0431 \bullet \mathrm{x}^{1.6025}(\mathrm{x}$ is DBH in $\mathrm{cm}$ ) the maximum cork oak density (trees ha ${ }^{-1}$ ) belonging to each size class was limited in the model (Natividade, 1950; Marín-Pageo and Camacho, 2011). 
Table 1

Specification of the main variables included in the model, respective description, measure units and references.

\begin{tabular}{|c|c|c|c|}
\hline \multicolumn{4}{|l|}{ Cork oak population dynamics } \\
\hline Variable & Description & Unit & Source \\
\hline \multicolumn{4}{|l|}{ Seedlings } \\
\hline Random acorns per tree & $\begin{array}{l}\text { Average } \mathrm{kg} \text { of acorns per tree } \\
\text { Minimum acorns per tree }=1.32 \\
\text { Maximum acorns per tree }=33.6\end{array}$ & $\mathrm{~kg}$ of acorns & $\begin{array}{l}\text { Herrera (1995), Cañellas et al. } \\
\text { (2007), Pérez-Ramos et al. } \\
\text { (2008) }\end{array}$ \\
\hline Random acorns Predation rate & $\begin{array}{l}\text { Proportion of predated acorns before } \\
\text { germination } \\
\text { Minimum acorns predation rate }=0.36 \\
\text { Maximum acorns predation rate }=0.83\end{array}$ & rate & Acácio et al. (2007) \\
\hline Random acorns insect damage rate & $\begin{array}{l}\text { Proportion of acorns damaged by insects } \\
\text { before germination } \\
\text { Minimum acorns insect damage rate }=0.09 \\
\text { Maximum acorns insect damage rate }=0.68\end{array}$ & rate & $\begin{array}{l}\text { Branco et al. (2002), Acácio } \\
\text { et al. (2007) }\end{array}$ \\
\hline Random acorns Acorn germination rate & $\begin{array}{l}\text { Proportion of acorns successfully germinated } \\
\text { Minimum acorns germination rate }=0.38 \\
\text { Maximum acorns germination rate }=0.84\end{array}$ & rate & $\begin{array}{l}\text { Herrera (1995), Acácio et al. } \\
\text { (2007), Arosa et al. (2015) }\end{array}$ \\
\hline Average seedlings fire mortality rate & $\begin{array}{l}\text { Proportion of seedling mortality by fire } \\
\text { Fire seedlings mortality }=0.0008\end{array}$ & rate & Catry et al. (2012) \\
\hline Random seedling drought mortality rate & $\begin{array}{l}\text { Proportion of seedling mortality by drought } \\
\text { Minimum seedlings drought mortality } \\
\text { rate }=0.68 \\
\text { Maximum seedlings drought mortality } \\
\text { rate }=0.70\end{array}$ & rate & Arosa et al. (2015) \\
\hline Random seedlings livestock mortality rate & $\begin{array}{l}\text { Proportion of seedling mortality by livestock } \\
\text { Minimum seedlings livestock mortality } \\
\text { rate }=0.28 \\
\text { Maximum seedlings livestock mortality } \\
\text { rate }=0.65\end{array}$ & rate & Plieninger et al. (2004) \\
\hline Random seedlings shrub clearing mortality rate & $\begin{array}{l}\text { Proportion of seedling mortality by shrub } \\
\text { clearing } \\
\text { Minimum seedlings shrub clearing mortality } \\
\text { rate }=0 \\
\text { Maximum seedlings shrub clearing mortality } \\
\text { rate }=1\end{array}$ & rate & Arosa et al. (2015) \\
\hline Average seedlings resprouting rate & $\begin{array}{l}\text { Proportion of seedling successfully } \\
\text { resprouted }=0.239\end{array}$ & rate & Arosa et al. (2015) \\
\hline \multicolumn{4}{|l|}{ Saplings } \\
\hline Average saplings fire mortality rate & $\begin{array}{l}\text { Proportion of saplings mortality by fire } \\
\text { Fire saplings mortality }=0.0008\end{array}$ & rate & Catry et al. (2012) \\
\hline Random saplings cohort $\times$ drought mortality rate & $\begin{array}{l}\text { Proportion of saplings mortality by drought } \\
\text { Minimum saplings drought mortality } \\
\text { rate }=0.68 \\
\text { Maximum saplings drought mortality } \\
\text { rate }=0.70\end{array}$ & rate & Arosa et al. (2015) \\
\hline Random saplings cohort $\times$ livestock mortality rate & $\begin{array}{l}\text { Proportion of saplings mortality by livestock } \\
\text { Minimum saplings livestock mortality } \\
\text { rate }=0.57 \\
\text { Maximum saplings livestock mortality } \\
\text { rate }=0.87\end{array}$ & rate & Plieninger et al. (2004) \\
\hline Random saplings cohort $\times$ shrub clearing mortality rate & $\begin{array}{l}\text { Proportion of saplings mortality by shrub } \\
\text { clearing } \\
\text { Minimum saplings shrub clearing mortality } \\
\text { rate }=0 \\
\text { Maximum saplings shrub clearing mortality } \\
\text { rate }=1\end{array}$ & rate & Arosa et al. (2015) \\
\hline DBH saplings & Saplings average diameter at breast height $=6$ & $\mathrm{~cm}$ & Pulido et al. (2013) \\
\hline \multicolumn{4}{|l|}{ Immature trees } \\
\hline Random immature trees cohort $\times$ fire mortality rate & $\begin{array}{l}\text { Proportion of immature trees mortality by fire } \\
\text { Minimum immature trees cohort } \times \text { fire } \\
\text { mortality rate }=0.06 \\
\text { Maximum immature trees cohort } \times \text { fire } \\
\text { mortality rate }=0.08\end{array}$ & rate & Catry et al. (2012) \\
\hline Random immature trees cohort $\times$ death rate & $\begin{array}{l}\text { Proportion of immature trees death } \\
\text { Minimum immature trees cohort } \times \text { death } \\
\text { rate }=0 \\
\text { Maximun immature trees cohort } \times \text { death } \\
\text { rate }=0.000092\end{array}$ & rate & Ribeiro and Surový (2008) \\
\hline DBH immature trees & $\begin{array}{l}\text { Immature trees average diameter at breast } \\
\text { height }=10\end{array}$ & $\mathrm{~cm}$ & Pulido et al. (2013) \\
\hline \multicolumn{4}{|l|}{ Adult trees } \\
\hline Adult trees per ha & Initial density of adult trees $=50$ & trees ha ${ }^{-1}$ & Joffre et al. (1999) \\
\hline Random adult trees fire mortality rate & $\begin{array}{l}\text { Proportion of adult trees mortality by fire } \\
\text { Minimum adult trees fire mortality } \\
\text { rate }=0.038214 \\
\text { Maximum adult trees fire mortality } \\
\text { rate }=0.04465\end{array}$ & rate & Catry et al. (2012) \\
\hline
\end{tabular}


Table 1 (Continued)

\begin{tabular}{|c|c|c|c|}
\hline \multicolumn{4}{|l|}{ Cork oak population dynamics } \\
\hline Variable & Description & Unit & Source \\
\hline Random adult trees & $\begin{array}{l}\text { Proportion of adult trees death } \\
\text { Minimum adult trees death rate }=0 \\
\text { Maximum adult trees death rate }=0.000092\end{array}$ & rate & Ribeiro and Surový (2008) \\
\hline DBH adult trees & $\begin{array}{l}\text { Adult trees average diameter at breast } \\
\text { height }=89\end{array}$ & $\mathrm{~cm}$ & Pulido et al. (2013) \\
\hline \multicolumn{4}{|l|}{ Cork oak management income per year } \\
\hline Random cork production per tree kg & $\begin{array}{l}\text { Average } \mathrm{kg} \text { of cork produced per tree } \\
\text { Minimum cork production per tree }=35.95534 \\
\text { Maximum cork production per tree }=69.56406\end{array}$ & $\mathrm{~kg}_{\text {tree }}-1$ & Pereira and Tomé (2004) \\
\hline Random income from cork per tree euros $\mathrm{kg}$ & $\begin{array}{l}\text { Average income in } € \text { per } \mathrm{kg} \text { of produced cork } \\
\text { Minimum income from cork per tree }=1.33 \\
\text { Maximum income from cork per tree }=3.33\end{array}$ & $€ \mathrm{~kg}^{-1}$ & Pinheiro and Ribeiro (2013) \\
\hline Average stripping cost cork extraction euros per kg & $\begin{array}{l}\text { Average cost of cork extraction in } € \text { per kg } \\
\text { Stripping cost cork extraction }=0.23\end{array}$ & $€ \mathrm{~kg}^{-1}$ & Pinheiro and Ribeiro (2013) \\
\hline Periodicity cork extraction & $\begin{array}{l}\text { Average years between cork extraction } \\
\text { Periodicity cork extraction }=9\end{array}$ & years & Pereira and Tomé (2004) \\
\hline Average shrub clearing cost euros per ha & $\begin{array}{l}\text { Average cost in } € \text { per cleared ha } \\
\text { Shrub clearing cost }=120\end{array}$ & $€ \mathrm{ha}^{-1}$ & Pinheiro et al. (2008) \\
\hline Average revenue from livestock euros per ha & $\begin{array}{l}\text { Average income in } € \text { of livestock per ha } \\
\text { Revenue form livestock }=22.4\end{array}$ & $€ \mathrm{ha}^{-1}$ & Pinheiro et al. (2008) \\
\hline
\end{tabular}
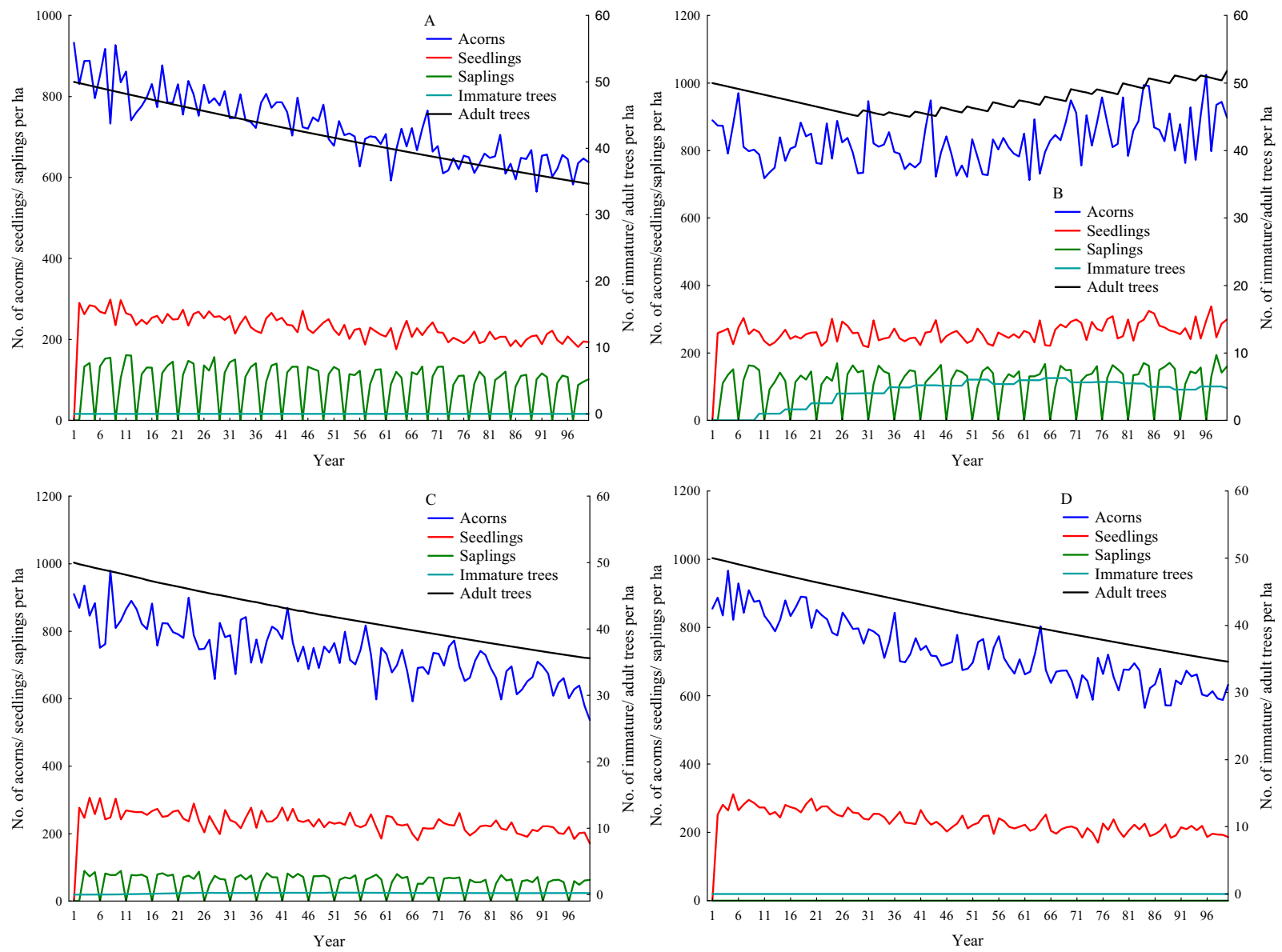

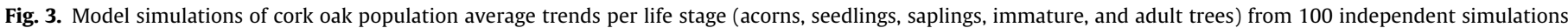

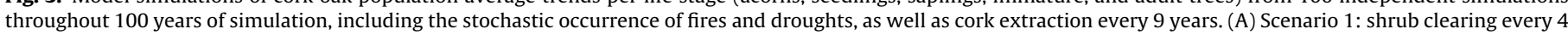

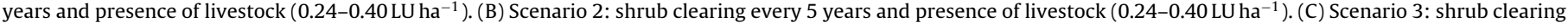
every 5 years and the presence of livestock $\left(0.40 \mathrm{LU} \mathrm{ha}^{-1}\right)$. (D) Scenario 4 : shrub clearing every year, while livestock was absent.

\subsubsection{Fire}

Fires are common phenomena in southern Europe and cork oaks are vulnerable to its effects, especially seedlings and saplings, but also immature and adult trees when burning occurs immediately after cork extraction (Cabezudo et al., 1995; Pausas, 1997; Moreira et al., 2007; Catry et al., 2012). Data from the Spanish Forest Service (magrama.gob.es) was used to parameterize annual frequency and to model the consequences of fires for each cork oak life stage, taking into account the respective tree diameters (DBH) (Catry et al., 2012). The average number of fires $(0.013 \pm 0.017$ fires.ha- 
1 ; mean \pm standard deviation) obtained per study unit in 44 years, from 100 independent stochastic simulations, was considered a reliable reproduction of the regional historical trends of fire events $(0.016 \pm 0.021$ fires ha- 1$)$ (magrama.gob.es).

\subsubsection{Drought}

Droughts contribute to cork oak population losses as it hampers regeneration and increases tree mortality (Acácio and Holmgren, 2014). Considering the historical trends of droughts in mainland Portugal from 1976 to 2007 (INAG, 2007), the drought effects per year were considered as direct constrains over seedlings and saplings viability, the more vulnerable classes to this environmental factor. After the calibration procedures, the average number of $0.24 \pm 0.078$ droughts.ha ${ }^{-1}$ (mean \pm standard deviation) obtained per study unit in 31 years, from 100 independent stochastic simulations, was considered a reliable reproduction of the regional historical trends of drought events $(0.24 \pm 0.43$ droughts.ha- 1$)$ (INAG, 2007).

\subsubsection{Livestock grazing}

The consequences of intense grazing are the death of young trees, soil compaction, decrease of water infiltration and local biodiversity decline (Plieninger et al., 2004; Plieninger, 2006). Grazing pressure was defined as the ratio between stocking rate, i.e. the number of livestock units (LU) per unit area and unit time, and biomass (total dry weight of vegetation per unit area and unit time) (Allen et al., 2011; Sales-Baptista et al., 2015). From the 50's to present times, stocking rates in montado ecosystems increased from $0.10-0.15$ to $0.24-0.40 \mathrm{LU} \mathrm{ha}^{-1}$ (Plieninger et al., 2004). Since the presence of livestock affects the survival of seedlings and saplings due to stem consumption, damages from livestock grazing were included in the model to assess the influence of livestock pressure in the cork oak regeneration. The livestock mortality rate was determined by the proportion of seedlings and saplings expected to die due to livestock grazing per year of simulation, ranging from 0.28 to 0.87 (Plieninger et al., 2004).

\subsubsection{Shrub clearing}

We included the effect of shrub clearing as a negative influence on seedlings and saplings viability since this is a common management practice in montado to control shrub invasion and to promote pasture growth (Pignatti, 1983; Pulido et al., 2001; Plieninger et al., 2003, 2004; Calvo et al., 2005). Contrary to the effect of shrub encroachment that enhances oak regeneration, promotes soil rehabilitation and prevents erosion, shrub clearing increases soil erosion and can derail the regenerating cork oak seedlings and saplings (Plieninger et al., 2004; Pulido and Díaz, 2005; Pérez-Ramos et al., 2008; Simões et al., 2009; Nunes et al., 2011; Arosa et al., 2015). Therefore, mortality due to shrub clearing was included in the model to assess the influence of this management practice in the cork oak regeneration.

\subsubsection{Cork oak natural mortality}

The cork oak natural mortality often represents a sum of continuous environmental and intrinsic processes with multiple contributors acting in the tree, such as age degeneration, insect damages or diseases, with unobvious cause-effect relationships concerning management practices and/or climate changes (Franklin et al., 1987; Branco et al., 2002; Camilo-Alves et al., 2013). In the model, we considered the effect of tree natural mortality over immature and adult cork oak trees using estimates from Ribeiro and Surový (2008) who determined the mortality trends of cork oak (trees ha ${ }^{-1}$ ) in Portugal based on aerial photographs interpretation.

\section{Economic balance}

The cork oak montado is a multifunctional agro-forestry ecosystem that can benefit society with many goods and services. However, the economic sustainability of cork oak montado depends mainly on the price of cork, associated with its quality and final use. Cork oak trees may live $250-350$ years but cork thickness and quality decreases and the limit to useful cork production is $150-200$ years. Trees with circumference at breast height more than $70 \mathrm{~cm}$ can be debarked, which corresponds to trees with 25-40 years of age, depending on site productivity and tree density. After the first cork debarking, the minimum period tolerable between cork extractions is 9 years (Pereira and Tomé, 2004; Pinheiro et al., 2008). Furthermore, depending of the montado management and land uses profit, the benefits can be also increased mainly by livestock production. On the other hand, shrub clearing and cork extractions represent the main costs associated with the montado management. Overall, the modelling of cork oak population dynamics, under scenarios where different management practices were simulated, includes the assessment of the possible economic incomes from montado by balancing the financial gains and losses between scenarios.

\section{Sensitivity analysis}

According to Lee et al. (2015) the purpose of a sensitivity analysis is provide a measure of the robustness of the model, measuring the sensitivity of the obtained results to changes in parameters, forcing functions and/or sub-models. Local sensitivity analysis (SA) was done by one-parameter-at-a-time technique (OAT), changing the population parameters of the model with $+1-10 \%$ and $+1-50 \%$ variation of the respective values and observing changes in the response of the selected state variables (Ligmann-Zielinska, 2013).

\section{Scenarios}

Our model was constructed in order to simulate realistic environmental conditions and management practices concerning cork production, and assess its influence on the cork oak population dynamics. We designed the scenarios, considering the most common management practices in montado. The design included the more limiting factors for cork oak regeneration, the number of livestock units and the frequency of shrub clearing. Four scenarios were designed, considering fire and droughts as stochastic events and cork oak extraction every 9 years. In all scenarios a mean number of 50 adult trees.ha- 1 was considered in the beginning of each simulation $(t=0)$, (Joffe et al., 1999), reproducing a typical montado. No seedlings, saplings and immature trees were considered in the beginning of simulations, since this is the typical situation in managed montados. Scenario 1 recreates the traditional management of the montado, with shrub clearing every 4 years and annual presence of livestock with values ranging between $0.24-0.40 \mathrm{LU} \mathrm{ha}^{-1}$ (the browsing index varied between $0.278-0.651$ on seedlings and between $0.574-0.875$ on saplings, Plieninger et al., 2004).

Scenario 2 was based on the scenario 1 trends, maintaining the density of livestock but with shrub clearing occurrence every 5 years. This allowed us to test the possible effects of a simple management alteration on the cork oak population dynamics.

In scenario 3, shrub clearing occurrence was set every 5 years as in scenario 2 but livestock density was increase $\left(0.40 \mathrm{LU} \mathrm{ha}^{-1}\right)$. The browsing index corresponded to 0.651 and 0.875 on seedlings and saplings, respectively (Plieninger et al., 2004).

In order to recreate a montado with annual soil mobilization to produce fodder for livestock at the end of summer, the scenario 4 assumes shrub clearing every year and absence of livestock. 
In all scenarios, mortality due to shrub clearing was based on the results of Arosa et al. (2015), assuming that all emerging seedlings and saplings die due to shrub clearing.

In order to detect possible effects of different management practices on the sustainability of the cork oak population, the Kruskal-Wallis non-parametric test was used since the variables tested did not meet the normality assumption, even after data transformation (McDonald, 2014): classes (i.e. average density of seedlings, saplings, immature trees and adult trees) and the income from cork oak management (i.e. average economic revenue), according to 2 time frames ( $t=50$ and $t=100$ ) were compared between scenarios do detect long-term changes. In case of significant differences proved by the Kruskal-Wallis test, post hoc comparisons between the groups were done using mean ranks (Siegel and Castellan, 1988). Here, significance levels were corrected according to the sequential Bonferonni technique. Differences were considered significant if their probability of occurring by chance was less than $5 \%$. Statistical analyses were carried out using the software Statistica version 8.0 (StatSoft Inc. 2007).

\section{Results}

\subsection{Sensitivity analysis}

The results from the OAT sensitivity analysis show that the parameters associated with seedlings, saplings, immature trees and adult tree cause individual changes on the modelling outcomes (Table 2). Random saplings cohort $\mathrm{x}$ livestock mortality rate was the parameter with the main key influence on the outputs of most surrogates.

\subsection{Cork oak population dynamics}

The scenario 1 involves the maintenance of montado (agroforestry) traditional management: a decline of most classes (acorns, seedlings, saplings and adult trees) was predicted throughout the simulation period (Fig. 3A). Anyway the most limiting factor to the overall population is associated to the immature trees, constrained by mortality associated with shrub clearing. Fires, droughts, livestock browsing and cork extraction seem to play secondary roles. The decrease in the number of adult trees will also restrict the amount of acorns available each year, and consequently the number of viable seedlings and saplings (Fig. 3A): the initial density of 50 adult trees ha ${ }^{-1}$ is expected to decrease to circa 35 trees ha $^{-1}$ in the end of simulation (i.e. $-30 \%$ of adult trees $/ 100$ years).

Conversely, when the implementation of 1-year delay in shrub clearing was tested in scenario 2, the final density of adult trees is expected to sustain or even increase ( 52 trees.ha $^{-1}$ ) throughout (i.e. $+4 \%$ of adult trees $/ 100$ years) (Fig. 3B). This slightly non-linear increase in the number of adult trees (Fig. 3), shows that some individuals reach the immature trees stage, compensating adults "natural mortality", raising the number of acorns and consequently the number of seedlings and saplings and creating a population of immature trees that will substitute the declining adults.

Nevertheless, the cork oak recovery achieved in scenario 2 by increasing shrub clearing periodicity for every 5 years, was completely withdrew by increasing livestock pressure as tested in scenario 3, with an overall decrease for all classes (Fig. 3C). The small amount of immature trees (Fig. 3C) is not enough to sustain in the long-term the population of adult trees. The estimated density of adult trees after 100 years of simulation decrease about 36 trees.ha ${ }^{-1}$ (i.e. $-28 \%$ of adult trees $/ 100$ years).

Intensive shrub clearing effects modelled in scenario 4 , resulted in neither saplings nor immature trees, being the most aggressive management as depicted in Fig. 3D. A decrease in the density of adult trees to 35 trees ha $^{-1}$ was estimated at the end of 100 years of simulation (i.e. $-30 \%$ of adult trees $/ 100$ years).

By comparing the four scenarios we did not detect significant differences in the number of seedlings at $t=50\left(\mathrm{H}_{3,96}=5.95\right.$, $\mathrm{p}=0.114$, Fig. $4 \mathrm{~A}$ ), while at $\mathrm{t}=100$ the number of seedlings in scenario 2 was significantly higher, with mean values of $299 \pm 185.63$ trees.ha ${ }^{-1}\left(\mathrm{H}_{3,96}=58.56, \mathrm{p}<0.001\right.$, Fig. $\left.4 \mathrm{~A}\right)$.

The low number of saplings in scenario 3 , with mean values of $67.99 \pm 64.05$ at $\mathrm{t}=50$ and $63.08 \pm 42.63$ trees.ha $^{-1}$ at $\mathrm{t}=100$, and the absence of saplings in scenario 4 at $t=50$ and $t=100$ was insufficient to withstand the population of immature and adult trees in the long-term $\left(\mathrm{H}_{3,96}=32.68, \mathrm{p}<0.001\right.$ and $\mathrm{H}_{3,96}=29.06, \mathrm{p}<0.001$, for scenario 3 and 4 respectively. Fig. 4A).

The results for immature trees are similar at $t=50$ and $t=100$ $\left(\mathrm{H}_{3,96}=94.29, \mathrm{p}<0.001\right.$, Fig. $\left.4 \mathrm{C}\right)$. In fact, the obtained low number of immature trees in scenarios 1,3 and 4 seems to be a consequence of the low availability of saplings due to intensive shrub clearing and presence of high number of livestock units. On the other hand, although immature trees have also been projected at low densities in scenario $2\left(6.06 \pm 5.90\right.$ and $4.81 \pm 4.07$ trees.ha $^{-1}$, at $\mathrm{t}=50$ and $\mathrm{t}=100$ respectively) it seems enough for the recovery of adult trees in the long term. This may be mainly due to the time to recover from the extended shrub clearing interval and the number of livestock units.

Regarding adult trees the results at $\mathrm{t}=50$ were significantly different between scenarios $\left(\mathrm{H}_{3,96}=46.65, \mathrm{p}<0.001\right.$, Fig. 4D), being the scenario 2 the only one with increasing number of adult trees facing the other scenarios $(46.53 \pm 3.63$ trees.ha- 1$)$. At $t=100$, with $51.68 \pm 8.19$ trees. $^{-1}$ in scenario $2\left(\mathrm{H}_{3,96}=60.77, \mathrm{p}<0.001 \mathrm{~m}\right.$ Fig. 4D) those differences were maintained

\section{Montado management}

The economic balances associated with scenario 1, 2, 3 and 4 resulted from the incomes related with cork extraction and livestock presence (and direct payments to farmers enrolled under the CAP) and losses from soil management and stripping cork costs. Interestingly, scenario 2 had the highest average predicted revenue from cork oak $\left(661.33 \pm 151.70 € \mathrm{ha}^{-1}\right.$ per year $)\left(\mathrm{H}_{3,396}=218.18\right.$, $\mathrm{p}<0.001$, Fig. 5), while average profits associated with scenarios 1 and 3 were almost identical $(564.94 \pm 118.20$ and $569.55 \pm 120.70$ $€$ ha $^{-1}$ per year, respectively). Scenario 4 generated the lowest average income $\left(275.13 \pm 112.39 € \mathrm{ha}^{-1}\right.$ per year $)$.

\section{Discussion}

The novelty of our study was the inclusion of several work previously published within a single modelling platform with the key-components of changing montado agro-forestry, with holistic and ecological relevance, namely by focusing on drivers with influence on the long-term sustainability of these ecosystems. In the montado, a dramatic mortality of cork oak has been taking place when trees were thinned to ease the use of farm machinery and promote wider crowns that yield more acorns (Pulido et al., 2001; Plieninger, 2007). Some strategies were created to preserve the montado and enhance its cultural and natural values and ecological services. In this perspective, legal protection of the trees and agro environmental schemes have been implemented to protect and promote tree plantation in the montado (Pinto-Correia et al., 2011). On the other hand, most montado ecosystems in Spain and Portugal are private and changes in the rural socioeconomic condition, in part induced by the previous Common Agricultural Policy (CAP), have contributed to the rural exodus due to poor conditions for agriculture, the peripheral location of the rural areas and the lack of employment (Van Doorn and Bakker, 2007). There- 
Table 2

Local sensitivity analysis (one-parameter-at-a-time) of the main state variables of the model to $+/-10 \%$ and $+/-50 \%$ variation of the parameter values.

\begin{tabular}{|c|c|c|c|c|c|}
\hline \multirow[t]{2}{*}{ State Variable } & \multirow[t]{2}{*}{ Parameter } & \multicolumn{4}{|c|}{ Sensitivity } \\
\hline & & $-50 \%$ & $-10 \%$ & $+10 \%$ & $+50 \%$ \\
\hline \multirow{18}{*}{ Seedlings } & Random seedlings shrub clearing mortality rate & 0.046 & -0.120 & -0.308 & -0.308 \\
\hline & Random seedling drought mortality rate & -0.184 & -0.121 & -0.036 & a \\
\hline & Random acorns germination rate & -0.597 & 0.045 & -0.045 & 0.234 \\
\hline & Random acorns predation rate & -0.126 & -0.004 & -0.243 & -0.174 \\
\hline & Random acorns insect damage rate & -0.136 & -0.234 & -0.177 & -0.166 \\
\hline & Average seedlings fire mortality rate & -0.121 & -0.121 & -0.397 & 0.197 \\
\hline & Random seedlings livestock mortality rate & -0.010 & 0.190 & 0.155 & -0.478 \\
\hline & Random saplings cohort $\times$ shrub clearing mortality rate & 0.247 & 0.338 & 0.099 & 0.099 \\
\hline & Random saplings cohort $\times$ drought mortality rate & -0.184 & -0.121 & -0.036 & a \\
\hline & Average saplings fire mortality rate & -0.121 & -0.121 & -0.397 & 0.197 \\
\hline & Random saplings cohort $\times$ livestock mortality rate & 1.228 & 2.245 & -0.408 & -0.377 \\
\hline & Random immature trees cohort $\times$ fire mortality rate & 0.214 & 0.090 & -0.102 & -0.026 \\
\hline & Random immature trees cohort $\times$ death rate & -0.209 & 0.196 & -0.099 & 0.025 \\
\hline & Period adult trees decay & -0.079 & 0.034 & 0.120 & -0.203 \\
\hline & Adult trees per ha & -0.559 & -0.333 & 0.420 & -0.196 \\
\hline & Random adult trees death rate & -0.039 & -0.051 & -0.325 & -0.189 \\
\hline & Random adult trees fire mortality rate & 0.142 & 0.060 & 0.053 & 0.078 \\
\hline & Random acorns per tree & -0.663 & -0.102 & 0.271 & 0.587 \\
\hline \multirow[t]{18}{*}{ Saplings } & Random seedlings shrub clearing mortality rate & 1.658 & 1.599 & 1.225 & 1.225 \\
\hline & Random seedling drought mortality rate & 2.595 & 1.193 & 1.360 & a \\
\hline & Random acorns germination rate & 0.015 & 1.479 & 1.878 & 3.079 \\
\hline & Random acorns predation rate & 1.538 & 2.054 & 1.405 & 0.257 \\
\hline & Random acorns insect damage rate & 2.809 & 1.260 & 1.825 & 0.861 \\
\hline & Average seedlings fire mortality rate & 1.656 & 1.411 & 2.118 & 2.076 \\
\hline & Random seedlings livestock mortality rate & 4.098 & 1.384 & 1.335 & -0.038 \\
\hline & Random saplings cohort $\times$ shrub clearing mortality rate & 0.247 & 0.338 & 0.099 & 0.099 \\
\hline & Random saplings cohort $\times$ drought mortality rate & 2.595 & 1.193 & 1.360 & a \\
\hline & Average saplings fire mortality rate & 1.656 & 1.411 & 2.118 & 2.076 \\
\hline & Random saplings cohort $\times$ livestock mortality rate & 11.535 & 7.816 & 0.502 & 0.286 \\
\hline & Random immature trees cohort $\times$ fire mortality rate & 2.437 & 1.809 & 2.291 & 2.426 \\
\hline & Random immature trees cohort $\times$ death rate & 1.643 & 1.729 & 1.277 & 2.287 \\
\hline & Period adult trees decay & 1.629 & 1.019 & 2.932 & 1.979 \\
\hline & Adult trees per ha & 0.252 & 2.158 & 4.240 & 3.693 \\
\hline & Random adult trees death rate & 1.881 & 1.446 & 2.521 & 2.487 \\
\hline & Random adult trees fire mortality rate & 1.384 & 1.421 & 0.765 & 2.113 \\
\hline & Random acorns per tree & -0.458 & 1.599 & 3.249 & 5.096 \\
\hline \multirow[t]{18}{*}{ Immature trees } & Random seedlings shrub clearing mortality rate & 0.710 & 0.746 & -0.011 & -0.011 \\
\hline & Random seedling drought mortality rate & 0.494 & 0.151 & 0.090 & a \\
\hline & Random acorns germination rate & -0.600 & -0.020 & 0.367 & 1.614 \\
\hline & Random acorns predation rate & 0.477 & 0.316 & 0.105 & 0.053 \\
\hline & Random acorns insect damage rate & 0.479 & 0.548 & 0.056 & -0.071 \\
\hline & Average seedlings fire mortality rate & 0.156 & 0.434 & 0.078 & 0.191 \\
\hline & Random seedlings livestock mortality rate & 1.123 & 0.362 & 0.137 & -0.551 \\
\hline & Random saplings cohort $\times$ shrub clearing mortality rate & 0.247 & 0.338 & 0.099 & 0.099 \\
\hline & Random saplings cohort $\times$ drought mortality rate & 0.494 & 0.151 & 0.090 & a \\
\hline & Average saplings fire mortality rate & 0.156 & 0.434 & 0.078 & 0.191 \\
\hline & Random saplings cohort $\times$ livestock mortality rate & 5.273 & 3.918 & -0.679 & -0.991 \\
\hline & Random immature trees cohort $\times$ fire mortality rate & 0.568 & 0.032 & 0.785 & -0.061 \\
\hline & Random immature trees cohort $\times$ death rate & -0.294 & 0.779 & 0.427 & 0.602 \\
\hline & Period adult trees decay & -0.164 & -0.207 & 0.033 & 0.483 \\
\hline & Adult trees per ha & -0.390 & 0.045 & 0.610 & 1.090 \\
\hline & Random adult trees death rate & 0.356 & -0.061 & 0.389 & 0.111 \\
\hline & Random adult trees fire mortality rate & 1.003 & 0.354 & 0.293 & 0.177 \\
\hline & Random acorns per tree & -0.423 & 0.181 & 0.738 & 1.576 \\
\hline \multirow[t]{18}{*}{ Adult trees } & Random seedlings shrub clearing mortality rate & 0.247 & 0.338 & 0.099 & 0.099 \\
\hline & Random seedling drought mortality rate & 0.147 & 0.179 & 0.078 & a \\
\hline & Random acorns germination rate & -0.179 & 0.103 & 0.332 & 0.351 \\
\hline & Random acorns predation rate & 0.178 & 0.249 & 0.086 & 0.001 \\
\hline & Random acorns insect damage rate & 0.142 & 0.063 & 0.064 & 0.043 \\
\hline & Average seedlings fire mortality rate & 0.233 & 0.179 & 0.246 & 0.140 \\
\hline & Random seedlings livestock mortality rate & 0.454 & 0.156 & 0.307 & -0.160 \\
\hline & Random saplings cohort $\times$ shrub clearing mortality rate & 0.247 & 0.338 & 0.099 & 0.099 \\
\hline & Random saplings cohort $\times$ drought mortality rate & 0.147 & 0.179 & 0.078 & a \\
\hline & Average saplings fire mortality rate & 0.233 & 0.179 & 0.246 & 0.140 \\
\hline & Random saplings cohort $\times$ livestock mortality rate & 2.016 & 2.006 & -0.205 & -0.381 \\
\hline & Random immature trees cohort $\times$ fire mortality rate & 0.160 & 0.165 & 0.223 & 0.223 \\
\hline & Random immature trees cohort $\times$ death rate & 0.154 & 0.245 & 0.135 & 0.229 \\
\hline & Period adult trees decay & -0.098 & 0.109 & 0.215 & 0.419 \\
\hline & Adult trees per ha & -0.421 & 0.138 & 0.504 & 0.795 \\
\hline & Random adult trees death rate & 0.248 & 0.086 & 0.251 & 0.255 \\
\hline & Random adult trees fire mortality rate & 0.227 & 0.228 & 0.252 & 0.155 \\
\hline & Random acorns per tree & -0.150 & 0.175 & 0.203 & 0.572 \\
\hline
\end{tabular}

\footnotetext{
a Sensitivity was not calculated considering that with the implemented variation, the parameter attained values higher than $100 \%$.
} 

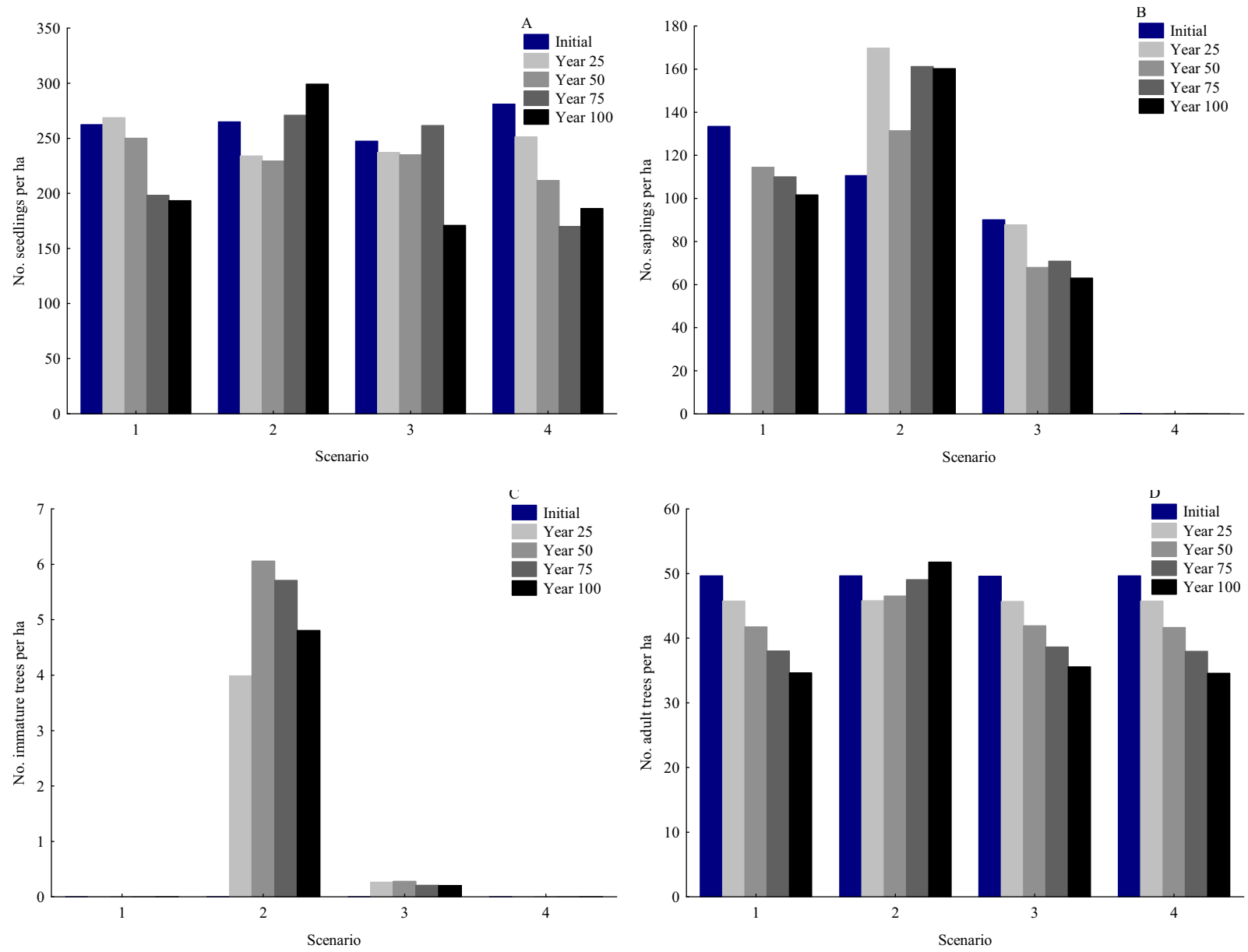

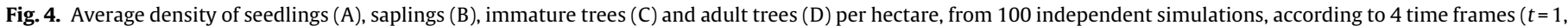
$t=25, t=75$ and $t=100)$ in each scenario considered.

fore, the importance of the socioeconomic situation in relation to land use change is generally recognized (Brandt et al., 1999): the direct aid to cereal areas and to some grazing animals into single payments to farmers, which are decoupled from production, resulted in land owners that have tended to replace sheep and goats with cattle, which in last 16 years increased its numbers by 2.5 times due to CAP support (Dýrmundsson, 2004; Pinto-Correia and Godinho, 2013; Pinto-Correia et al., 2014; Viegas et al., 2014). After the abandonment of cereal crops and livestock rearing, during the 70's, shrub clearing and rotational ploughing became common practices to control shrub invasion, to promote pasture production and prevent fire (Pignatti, 1983; Pulido et al., 2001; Plieninger et al., $2003,2004,2005)$. The heavy cattle breeds or higher livestock rates, together with deep ploughing of cultivated crops, is undoubtedly affecting natural regeneration and many authors estimate these factors as a major threat to the montado ecosystem (Pinto-Correia and Mascarenhas, 1999; Bugalho et al., 2011; Moreno and Pulido, 2009).

\section{Main limitations to regeneration}

Overall, our results indicate that the main limitations to the lack of cork oak regeneration in montado ecosystems rise from land management practices, rather than environmental factors. In fact, the obtained results suggest that delaying shrub clearing and limiting the quantity of livestock units might constitute a suitable measure to allow the long-term sustainability of the montado. A minimal delay of one year in soil ploughing will be enough for landowners to ensure the maintenance/increase in the number of immature and adult trees as well as the long-term sustainability of the montado ecosystem. Since cork is the most profitable product obtained from the montado, an increase in the density of adult trees would have also a direct positive effect on the economic balance of agroforestry "crop". On the other hand, by increasing livestock densities, cork oak regeneration is severely constrained due to the consumption of seedlings and saplings, and the regeneration cycle would eventually collapse. A similar result is obtained when there is a continuous use of heavy machinery. Other conventional semi quantitative studies that investigated the effects of montado changes have come to similar conclusions, corroborating that livestock pressure acts as a main driver determining the rates of montado loss, although not explaining with detail the process beneath (Blondel, 2006; Plieninger, 2007; Gaspar et al., 2008; Bugalho et al., 2011). Acorn predation and browsing, as well as trampling of seedlings are the main pressures of overgrazing, associated with the intensity and type of grazing (livestock type, breeds, density, length of time in pasture) (Pulido and Díaz, 2005). Our results identify limits to the carrying capacity of the montado near 0.40 LU ha- 1 , from which the future of the montado sustainability would be seriously threatened. This outcome also demonstrates that care must be taken with the CAP support to increasing the number of livestock per ha. Also Baeza, 2004 and Calvo et al., 2012 limit the number of LU.ha-1 near 1, which based on our results, may put the montado agroecosystem at risk.

Results relative to shrub clearing demonstrated that most of the montado loss is associated with land management practices. 


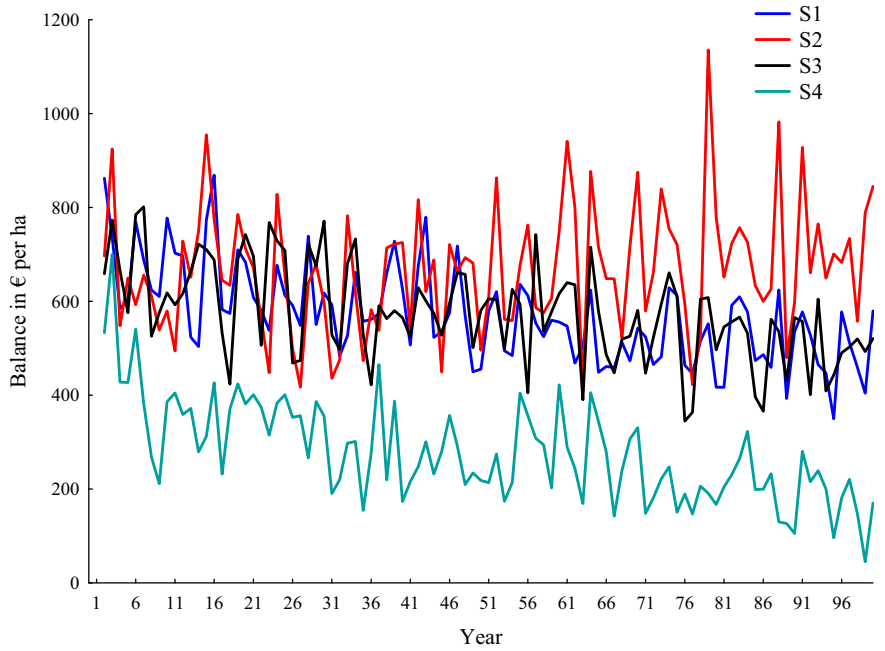

Fig. 5. Predicted average economic balance (€.ha- 1 ) for scenarios $1,2,3$ and 4 , from 100 independent simulations throughout 100 years of simulation.

Shrub clearing might hinder landscape heterogeneity and damage the fungal community in montado, decreasing the mycorrhizal community that is part of the symbiosis most intimately connected to the soil and most directly involved in uptaking nutrients and influencing soil properties (Azul, 2002; Azul et al., 2010). The period between consecutive shrub clearings supports different management objectives: intensive shrub clearing every three years will favour pastureland for livestock grazing and decreasing shrub growing will neglect its positive protector effect over regeneration (Canteiro et al., 2011; Simões et al., 2015). This agrees with our results, where short periods between clearings would inhibit the regeneration of trees, since mechanical clearing is a non-selective tool that destroys most seedlings (Arosa et al., 2015), thus the absence of immature trees directly affects negatively the population of adult trees. According to our long term results, we assume that extending shrub clearing for longer periods would benefit natural regeneration, which is in agreement with other short term studies (Canteiro et al., 2011; Godinho et al., 2014; Simões et al., 2016). In fact, other authors' conclusions suggest maintaining shrub cover for a period between 7 and 12 years to help cork oak regeneration and promote tree nursery and soil rehabilitation. Conversely, periods longer than 12 years could facilitate fire spread due to the accumulation of dead material (Canteiro et al., 2011). EU programs have only been subsidizing planting young cork oak trees but results obtained by Arosa et al. (2015) confirmed that direct seeding (or natural regeneration) of cork oak is a good alternative to facilitate regeneration, because emergence success ranged between $43.5 \%$ and $63.9 \%$. Agricultural policies should consider this information as they play an important role in management decision and can contribute to further degradation of tree cover (Pinto-Correia and Vos, 2004).

\section{Future perspectives}

The developed dynamic model allowed predicting long term trends in cork oak local population, including those attributable to changes in habitat due to different sources of disturbance and management scenarios (Winkler, 2006). Therefore, this study represents an early step to support strategic options for impact mitigation and management by providing projections of long-term indicator trends under realistic social-ecological change scenarios (Bastos et al., 2015). Although the projections recreates realistically the known cork oak regeneration patters occurring in montado regions, some limitations arise when considering validation as a fundamental process to assess the relative accuracy of the model response facing independent real data (Rykiel, 1996). The validation of the predictions was not possible in this study due to the impracticality of an immediate validation of future scenarios, which can only be done after several years of collecting relevant site-specific information under well-known local environmental conditions (Glenz et al., 2001; Chaloupka, 2002).

Our academic and user-friendly model, after specific calibration and validation, could be used to support specific farmer decisions in the management of cork oak savannas and support agroforestry extension services. Furthermore, large-scale analyses are mandatory to fully understand the role of multi-scale cumulative drivers influencing the regeneration process and the role of policies in managing this ecosystem (Godinho et al., 2014). In this context, the combination of local population dynamics (temporal) and regional distributional (spatial) models can help to assess and predict how anthropogenic and environmental changes will affect the abundance and displacement of vulnerable species or communities in disturbed ecosystems and regions (Guisan and Thuiller, 2005). Besides, models are useful to identify areas where the conflict between the previous forecasted trends and drivers of pressure are of major conservationist concern, by allowing the integration of the ecological consequences from local to regional levels (Bjørnstad et al., 1999; Vicente et al., 2011). Model-based research resulted very useful as an investigative tool to predict the outcome of alternative scenarios, guiding current restoration options from predicted future targets (Bastos et al., 2012). Future work should be directed to develop the restoration strategies of cork oak montados, which will contribute to fight desertification, protect biodiversity, mitigate climate change and promote the sustainable development of local communities.

\section{Conclusion}

The capacity to accurately predict responses of species to landscape changes is crucial for conservation planning and to support key ecosystems management (Kandziora et al., 2013). In montado ecosystems, there is a lack of evaluation on the long-term ecological changes associated with management practices, whose consequences might represent major limiting factors to the ecological and economic sustainability of this valuable agro-ecosystem. The developed dynamic model allowed integrating and simulating the main factors affecting the long-term sustainability of the montado system, namely the major limiting factors driving the lack of regeneration of cork oak trees in montados. The number of livestock units per ha and short shrub clearing intervals were identified as the main limiting factors for the long term sustainability of this agroforestry ecosystem. Thus, it should be considered a maximum quantity of livestock of 0.40 LU.ha $^{-1}$ and the minimum periodicity between soil ploughing to 5 years. Specific management practices are suggested to overcome the sustainability of the identified problems.

\section{Acknowledgements}

This work was supported by the FCT (Portuguese Foundation for Science and Technology) under a Ph.D. grant [SFRH/BD/70708/2010]. R. Bastos is funded by FCT through the doctoral grant SFRH/BD/102428/2014. S. Costa is funded by the FCT through the post-doctoral grant SFRH/BPD/102438/2014. We are grateful to Alfredo Sendim from Herdade do Freixo do Meio who kindly allowed us to develop this work at his property. 


\section{Appendix A. Supplementary data}

Supplementary data associated with this article can be found, in the online version, at http://dx.doi.org/10.1016/j.ecolmodel.2016. 10.008 .

\section{References}

Acácio, V., Holmgren, M., 2014. Pathways for resilience in Mediterranean cork oak land use systems. Ann. For. Sci. 71, 5-13.

Acácio, V., Holmgren, M., Jansen, P.A., Schrotter, O., 2007. Multiple recruitment limitation causes arrested succession in Mediterranean cork oak systems. Ecosystems 10, 1220-1230.

Acácio, V., Holmgren, M., Rego, F., Moreira, F., Mohren, G.M., 2009. Are drought and wildfires turning Mediterranean cork oak forests into persistent shrublands? Agrofor. Syst. 76, 389-400.

Acácio, V., Holmgren, M., Moreira, F., Mohren, G.M.J., 2010. Oak persistence in Mediterranean landscapes: the combined role of management, topography, and wildfires. Ecol. Soc. 15, 40.

Allen, V.G., Batello, C., Berretta, E.J., Hodgson, J., Kothmann, M., Li, X., McIvor, J., Milne, J., Morris, C., Peeters, A., Sanderson, M., 2011. An international terminology for grazing lands and grazing animals. Grass Forage Sci. 66, 2-28.

Arosa, M.L., Ceia, R.C., Costa, R.S., Freitas, H., 2015. Factors affecting cork oak (Quercus suber) regeneration: acorn sowing success and seedling survival under field conditions. Plant Ecol. Divers., http://dx.doi.org/10.1080/17550874. 2015.1051154.

Assmann, E., Gardiner, S., 1970. The Principles of Forest Yield Study. Pergamon Press, Oxford.

Azul, A.M., Sousa, J.P., Agerer, R., Martín, M.P., Freitas, H., 2010. Land use practices and ectomycorrhizal fungal communities from oak woodlands dominated by Quercus suber L. considering drought scenarios. Mycorrhiza 20 (2), 0261-0262, http://dx.doi.org/10.1007/s00572-009-0261-2.

Azul, A.M., 2002. Diversidade De Fungos Ectomicorrízicos Em Ecossitemas De Montado Ph.D. Thesis. Department of Botany, The University of Coimbra, Coimbra, Portugal.

Baeza, M.J., 2004. El manejo del matorral en la prevención de incendios forestales. In: Vallejo, V.R., Alloza, J.A. (Eds.), Avances En El Estudio De La Gestión Del Monte Mediterráneo. Fundación Centro de Estudios Ambientales del Mediterráneo, Valencia.

Bastos, R., Santos, M., Ramos, J.A., Vicente, J., Guerra, C., Alonso, J., Honrado, J., Ceia, R.S., Timóteo, S., Cabral, J.A., 2012. Testing a novel spatially-explicit dynamic modelling approach in the scope of the laurel forest management for the endangered Azores bullfinch (Pyrrhula murina) conservation. Biol. Conserv. $147,243-254$.

Bastos, R., Pinhanços, A., Santos, M., Fernandes, R., Vicente, J., Morinha, F., Honrado, J.P., Travassos, P., Barros, P., Cabral, J.A., 2015. Evaluating the regional cumulative impact of wind farms on birds: how spatially-explicit dynamic modelling can improve impact assessments and monitoring? J. Appl. Ecol., http://dx.doi.org/10.1111/1365-2664.12451.

Bjørnstad, O.N., Ims, R.A., Lambin, X., 1999. Spatial population dynamics: analyzing patterns and processes of population synchrony. Trends Ecol. Evol. 14, 427-431.

Blondel, J., 2006. The design of Mediterranean landscapes: a millennial story of human and ecological systems during the historic period. Hum. Ecol. 34 , 713-729.

Branco, M., Branco, C., Merouani, H., Almeida, M.H., 2002. Germination success, survival and seedling vigour of Quercus suber acorns in relation to insect damage. For. Ecol. Manage. 166, 159-164.

Brandt, J., Primdahl, J., Reenberg, A., 1999. Rural land-use and landscape dynamics-analysis of 'driving forces' in space and time. In: Kronert, R., Baudry, J., Bowler, I.R., Reenberg, A. (Eds.), Land-Use Changes and Their Environmental Impact in Rural Areas in Europe. UNESCO, Paris, pp. 81-102.

Bugalho, M.N., Caldeira, M.C., Pereira, J.S., Aronson, J., Pausas, J.G., 2011. Mediterranean cork oak savannas require human use to sustain biodiversity and ecosystem services. Front. Ecol. Environ. 9, 278-286.

Cañellas, I., Roig, S., Poblacione, M.J., Gea-Izquierdo, G., Olea, L., 2007. An approach to acorn production in Iberian dehesas. Agrofor. Syst. 70, 3-9.

Cabezudo, B., La Torre, A.P., Nieto, J.M., 1995. Regeneración de un alcornocal incendidado en el Sur de España (Istán, Málaga). Acta Bot. Malacitana 20 143-151.

Callaway, R.M., Walker, L.R., 1997. Competition and facilitation: a synthetic approach to interactions in plant communities. Ecology 78, 1958-1965.

Calvo, L., Tárrega, R., Luís, E., Valbuena, L., Marcos, E., 2005. Recovery after experimental cutting and burning in three shrub communities. Plant Ecol. 180, $175-185$.

Calvo, L., Baeza, J., Marcos, E., Santana, V., Papanastasis, V.P., et al., 2012. Post-fire management of shrublands. In: Moreira, F. (Ed.), Post-fire Management and Restoration of Southern European Forest. Managing Forest Ecosystems, Vol 24. Springer, New York, pp. 293-319.

Camilo-Alves, C.S.P., da Clara, M.I.E., Ribeiro, N.M.C.A., 2013. Decline of Mediterranean oak trees and its association with Phytophthora cinnamomi: a review. Eur. J. For. Res. 132, 411-432.
Canteiro, C., Pinto-Cruz, C., Paula Simões, M., Gazarini, L., 2011. Conservation of Mediterranean oak woodlands: understory dynamics under different shrub management. Agrofor. Syst. 82, 161-171.

Catry, F.X., Moreira, F., Pausas, J.G., Fernandes, P.M., Rego, F., Cardillo, E., Curt, T., 2012. Cork oak vulnerability to fire: the role of bark Harvesting, tree characteristics and abiotic factors. PLoS One 7 (6), e39810, http://dx.doi.org/10 1371/journal.pone.0039810.

Ceia, R.S., Ramos, J.A., 2014. Birds as predators of cork and holm oak pests. Agrofor. Syst., 10.1007/s10457-014-9749-7.

Chaloupka, M., 2002. Stochastic simulation modelling of southern Great Barrier Reef green turtle population dynamics. Ecol. Modell. 148, 79-109.

Díaz-Fernández, P.M., Climent, J., Gil, L., 2004. Biennial acorn maturation and its relationship with flowering phenology in Iberian populations of Quercus suber. Trees Struct. Funct. 18, 615-621.

Dýrmundsson, O.R., 2004. Sustainability of sheep and goat production in North European countries - from the Arctic to the Alps. In: 55th Annual Meeting of the European Association for Animal Production, Bled, Slovenia.

Deleuze, C., Herve, J.C., Colin, F., Ribeyrolles, L., 1996. Modelling crown shape of Picea abies: spacing effects. Can. J. For. Res. 26, 1957-1966.

Dolezal, J., Ishii, H., Vetrova, V.P., Sumida, A., Hara, T., 2004. Tree growth and competition in a Betulaplatyphylla-Larixcajanderi post- fire forest in central Kamchatka. Ann. Bot. 94, 333-343.

Elena-Rosselló, J.A., Río, J.M., GarcíaValdecantos, J.L., Santamaría, I.G., 1993. Ecological aspects of the floral phenology of the cork oak (Q. suber L.): why do annual and biennal biotype appear? Pp. 114s-121s. In: Genetics of oaks. proc. IUFRO working party meeting, 2-6 Sept. 1991. Arboretum National des Barres, France. INRA Paris.

Fei, S., Steiner, K.C., 2008. Relationships between advance oak regeneration and biotic and abiotic factors. Tree Physiol. 28, 1111-1119.

Fernandes, C., Cabral, J.A., Crespí, A.L., Hughes, S.J., Santos, M., 2013. Converting simple vegetation surveys in functional dynamics. Acta Oecol. 48, 37-46.

Flores-Martinez, A., Ezcurra, E., Sanchez-Colon, S., 1994. Effect of Neobuxbaumia tetetzo on growth and fecundity of its nurse plant Mimosa luisana. J. Ecol. 82, 325-330.

Franklin, J.F., Shugart, H.H., Harmon, M.E., 1987. Tree death as an ecological process. Bioscience 37, 550-556.

Gómez-Aparicio, L., Pérez-Ramos, I.M., Mendoza, I., Matías, L., Quero, J.L., Castro, J., Zamora, R., Marañón, T., 2008. Oak seedling survival and growth along resource gradients in Mediterranean forests: implications for regeneration in current and future environmental scenarios. Oikos 117, 1683-1699.

Gaspar, P., Escribano, M., Mesías, F.J., Rodriguez de Ledesma, A., Pulido, F., 2008. Sheep farms in the Spanish rangelands (dehesas): typologies according to livestock management and economic indicators. Small Rumin. Res. 74, 52-63.

Gimeno, T.E., Pías, B., Lemos-Filho, J.P., Valladares, F., 2009. Plasticity and stress tolerance override local adaptation in the responses of Mediterranean holm oak seedlings to drought and cold. Tree Physiol. 29, 87-98.

Glenz, C., Massolo, A., Kuonen, D.S., Schlaepfer, R., 2001. A wolf habitat suitability prediction study in Valais (Switzerland). Landsc. Urban Plann. 55, 55-65.

Godinho, S., Guiomar, N., Machado, R., Santos, P., Sá-Sousa, P., Fernandes, J.P., Neves, N., Pinto-Correia, T., 2014. Assessment of environment, land management, and spatial variables on recent changes in montado land cover in southern Portugal. Agrofor. Syst., http://dx.doi.org/10.1007/s10457-014-97577.

González, D., Cabral, J.A., Torres, L., Santos, M., 2015. A cohort-based modelling approach for managing olive moth Prays oleae (Bernard, 1788) populations in olive orchards. Ecol. Modell. 296, 46-56.

Guisan, A., Thuiller, W., 2005. Predicting species distribution: offering more than simple habitat models. Ecol. Lett. 8, 993-1009.

Harper, J.L., 1977. Population Biology of Plants. Academic Press, London, UK.

Herrera, J., 1995. Acorn predation and seedling production in a low-density population of cork oak (Quercus suber L.). For. Ecol. Manage. 76, 197-201.

Holmgren, M., Scheffer, M., Huston, M.A., 1997. The interplay of facilitation and competition in plant communities. Ecology 78, 1966-1975.

INAG, 2007. Preliminary Country Report, Contribuição portuguesa para o relatório da Comissão Europeia Water Scarcity \& Droughts -In-depth assessment, Second Interim Report, Instituto da Água, Ministério do Ambiente Ordenamento do Território e Desenvolvimento Regional.

Joffre, R., Rambal, S., Ratte, J.P., 1999. The dehesa system of southern Spain and Portugal as a natural ecosystem mimic. Agrofor. Syst. 45, 57-79.

Jørgensen, S.E., 1994. Models as instruments for combination of ecological theory and environmental practice. Ecol. Modell. 75, 5-20.

Jørgensen, S.E., 2001. Fundamentals of Ecological Modelling, 3rd ed. Elsevier, Amsterdam.

Kandziora, M., Burkhard, B., Müller, F., 2013. Interactions of ecosystem properties, ecosystem integrity and ecosystem service indicators - a theoretical matrix exercise. Ecol. Indic. 28, 54-78.

Kenkel, N.C., 1988. Pattern of self-thinning in Jack pine: testing the random mortality hypothesis. Ecology 69, 1017-1024.

Lee, J.S., Filatova, T., Ligmann-Zielinska, A., Hassani-Mahmooei, B., Stonedahl, F., Lorscheid, I., Voinov, A., Polhil, G., Sun, Z., Parker, D.C., 2015. The complexities of agent-basedmodeling output analysis. J. Artif. Soc. Soc. Simulat. 18 (4), 4.

Ligmann-Zielinska, A., 2013. Spatially-explicit sensitivity analysis of an agent-basedmodel of land use change. Int. J. Geogr. Inf. Sci. 27 (9), 1764-1781.

Müller, F., 2005. Indicating ecosystem and landscape organisation. Ecol. Indic. 5, 280-294. 
Marín-Pageo, F., Camacho, V., 2011. Di Bérengerís method application in southwest iberian cork oak stands. L'italia Forestale e Montana 66 (1), 31-40.

McDonald, J.H., 2014. Handbook of Biological Statistics, 3rd ed. Sparky House Publishing, USA, pp. 157-164.

Montero, G., Cañellas, I., 2003. El Alcornoque Manual De Reforestación Y Cultivo. Mundi-Prensa, Madrid.

Moreira, F., Duarte, I., Catry, F., Acácio, V., 2007. Cork extraction as a key factor determining post-fire cork oak survival in a mountain region of southern Portugal. For. Ecol. Manage. 253, 30-37.

Moreno, G., Pulido, F.J., 2009. The functioning, management and persistence of dehesas. In: Rigueiro-Rodríguez, A., McAdam, J., Mosquera-Losada, M.R. (Eds.) Agroforestry in Europe, Current Status and Future Prospects. Springer, The Netherlands, pp. 127-160.

Muick, P.C., Bartolome, J.W., 1987. An Assessment of Natural Regeneration of Oaks in California Division of Forestry. University of California, Berkeley, CA, 101 pp.

Natividade, J.V., 1950 - Subericultura. Dir. Gral. Dos Serv. Forestaira. Lisboa. ed. española, 1992. MAPA, Madrid.

Nunes, A.N., De Almeida, A.C., Coelho, C.O., 2011. Impacts of land use and cover type on runoff and soil erosion in a marginal area of Portugal. Appl. Geogr. 31, 687-699.

Olea, L., López-Bellido, RJ., Poblaciones, M.J., 2005. Europe types of silvopastoral systems in the Mediterranean area: dehesa. In: Mosquera, M.R., Rigueiro, A., McAdam, J. (Eds.), Silvopastoralism and Sustainable Land Management. CABI Publishing, Lugo, Spain, pp. 30-35.

Pérez-Ramos, I.M., Urbieta, I.R., Marañón, T. Zavala, M. A., Kobe, R.K., 2008. Seed removal in two coexisting oak species: ecological consequences of seed size. plant cover and seed drop timing. Oikos 117, 1386-1396.

Paracchini, M.L., Petersen, J.E., Hoogeveen, Y., Bamps, C., Burfield, I., van Swaay, C. 2008. High Nature Value Farmland in Europe. An Estimate of the Distribution Patterns on the Basis of Land Cover and Biodiversity Data. Office for Official Publications of the European Communities, Luxemburg.

Pausas, J.G., Marañón, T., Caldeira, M., Pons, J., et al., 2009. Natural Regeneration. In: Aronson (Ed.), pp. 115-124, Chapter 10

Pausas, J.G., 1997. Resprouting of Quercus suber in NE Spain after fire. J. Veg. Sci. 8 703-706.

Pereira, H., Tomé, M., 2004. Cork Oak Encyclopedia of Forest Sciences. Elsevier, Oxford, pp. 613-620

Pignatti, S., 1983. Human impact on the vegetation of the Mediterranean Basin. In: Holzner, W., Werger, M.J.A., Ikusima, I. (Eds.), Man’s Impact on Vegetation, 3. Geobotany, pp. 151-161.

Pinheiro, A.C., Ribeiro, N.A., 2013. Forest property insurance: an application to Portuguese woodlands. Int. J. Sustain. Soc. 5, 284-295.

Pinheiro, A.C., Ribeiro, N.A., Surový, P., Ferreira, A.G., 2008. Economic implications of different cork oak forest management systems. Int. J. Sustain. Soc. 1 149-157.

Pinto-Correia, T., Fonseca, A., 2009. Historical perspective of Montados: the Évora case study. In: Aronson, J., Santos Pereira, J., Pausas, J.G. (Eds.), Cork Oak Woodlands in Transition: Ecology, Management, and Restoration of an Ancient Mediterranean Ecosystem. Island Press, Washington DC, pp. 49-58.

Pinto-Correia, T., Godinho, S., 2013. Changing agriculture changing landscapes: what is going on in the high valued montado. In: Ortiz-Miranda, D., Moragues-Faus, A., Arnalte Alegre, E. (Eds.), Agriculture in Mediterranean Europe: Between Old and New Paradigms (Research in Rural Sociology and Development, Vol. 19. Emerald Group Publishing Limited, Bingley, pp. 75-90.

Pinto-Correia, T., Mascarenhas, J., 1999. Contribution to the extensification/intensification debate: new trends in the Portuguese montado. Landsc. Urban Plann. 46, 125-131.

Pinto-Correia, T., Vos, W., 2004. Multifunctionality in Mediterranean landscapes: past and future. In: Jongman, R. (Ed.), The New Dimensions of the Europeanlandscape. Wagenigen UR Frontis Series, Vol. 4. Springer, Dordrecht, The Netherlands, pp. 135-164

Pinto-Correia, T., Ribeiro, N., Sá-Sousa, P., 2011. Introducing the montado, the cork and holm oak agroforestry system of Southern Portugal. Agrofor. Syst. 82 , 99-104.

Pinto-Correia, T., Menezes, H., Barroso, F., 2014. The landscape as an asset in Southern European fragile agricultural systems: contrasts and contradictions in land managers attitudes and practices. Landsc. Res. 39, 205-217.

Plieninger, T., Pulido, F.J., Konold, W., 2003. Effects of land-use history on size structure of holm oak stands in Spanish dehesas: implications for conservation and restoration. Environ. Conserv, 30, 61-70.
Plieninger, T., Pulido, F.J., Schaich, H., 2004. Effects of land-use and landscape structure on holm oak recruitment and regeneration at farm level in Quercus ilex L. dehesas. J. Arid Environ. 57, 345-364.

Plieninger, T., 2006. Habitat loss, fragmentation, and alteration-quantifying the impact of land-use changes on a Spanish dehesa landscape by use of aerial photography and GIS. Landsc. Ecol. 21, 91-105.

Plieninger, T., 2007. Compatibility of livestock grazing with stand regeneration in Mediterranean holm oak parklands. J. Nat. Conserv. 15, 1-9.

Pulido, F.J., Díaz, M., 2005. Regeneration of a Mediterranean oak: a whole cycle approach. Écoscience 12, 92-102.

Pulido, F.J., Díaz, M., Trucios, S.J.H., 2001. Size structure and regeneration of Spanish holm oak Quercus ilex forests and dehesas: effects of agroforestry use on their long-term sustainability. For. Ecol. Manage. 146, 1-13.

Pulido, F., McCreary, D., Cañellas, I., McClaran, M., Plieninger, T., 2013. Oak regeneration: ecological dynamics and restoration techniques. In: Campos, P., Huntsinger, L., Oviedo Pro, J.L., Starrs, P.F., Díaz, M., Standiford, R.B., Montero, G. (Eds.), Mediterranean Oak Woodland Working Landscapes. Springer Netherlands, The Netherlands, pp. 123-144.

Ribeiro, N.A., Surový, P., 2008. Inventário Nacional De Mortalidade De Sobreiro Na Fotografia aérea Digital De 2004/2006. ICAM, MADRP, AFN. Évora University Publishings.

Rykiel, E.J., 1996. Testing ecological models: the meaning of validation. Ecol. Modell. 90, 229-244.

Sales-Baptista, E., Cancela d'Abreu, M., Ferraz-de-Oliveira, M.I., 2015. Overgrazing in the Montado? The need for monitoring grazing pressure at paddock scale. Agrofor. Syst., http://dx.doi.org/10.1007/s10457-014-9785-3.

Santos, M., Bastos, R., Cabral, J.A., 2013. Converting conventional ecological datasets in dynamic and dynamic spatially explicit simulations: current advances and future applications of the Stochastic Dynamic Methodology (StDM). Ecol. Modell. 258, 91-100.

Serrada, R., 2002. Apuntes De Selvicultura. E.U.I.T.F, Madrid.

Siegel, S., Castellan, N.J., 1988. Nonparametric Statistics for the Behavioral Sciences, 2nd ed. McGraw-Hill, New York, NY.

Simões, M.P., Madeira, M., Gazarini, L., 2009. Ability of Cistus L. shrubs to promote soil rehabilitation in extensive oak woodlands of Mediterranean areas. Plant Soil 323, 249-265.

Simões, M.P., Belo, A.F., Fernandes, M., Madeira, M., 2016. Agrofor. Syst. 90, 107, doi:10.1007/s10457-015-9818-6.

Smit, C., Díaz, M., Jansen, P., 2009. Establishment limitation of holm oak (Ouercus ilex subsp. ballota (Desf.) Samp.) in a Mediterranean savanna-forest ecosystem. Ann. For. Sci. 66, 1-7.

Sterman, J.D., 2001. System dynamics modelling: tools for learning in a complex world. Calif. Manage. Rev. 43, 8-25.

Stoll, S., Frenzel, M., Burkhard, B., Adamescu, M., Augustaitis, A., Baeßler, C., Bonet, F.J., Cazacu, C., Cosor, G.L., Díaz-Delgado, R., Carranza, M.L., Grandin, U., Haase, P., Hämäläinen, H., Loke, R., Müller, J., Stanisci, A., Staszewski, T., Müller, F., 2015. Assessment of ecosystem integrity and service gradients across Europe using the LTER Europe network. Ecol. Modell. 295, 75-87.

Tutin, T.G., Heywood, V.H., Burges, N.A., Valentine, D.H., Walters, S.M., Webb, D.A., 1964. Flora europaea. Lycopodiaceae to Platanaceae, Vol. 1. Cambridge University Press, Cambridge, UK.

Van Doorn, M.M., Bakker, A.M., 2007. The destination of arable land in a marginal agricultural landscape in South Portugal: an exploration of land use change determinants. Landsc. Ecol. 22, 1073-1087.

Vicente, J., Randin, C.F., Gonçalves, J., Metzger, M., Lomba, A., Honrado, J., Guisan, A., 2011. Where will conflicts between alien and rare species occur after climate and land-use change? A test with a novel combined modeling approach. Biol. Invasions 13, 1209-1227.

Viegas, I., Aguiar Fontes, M., Lima Santos, J., 2014. Produção de carne de bovino em sistemas silvo-pastoris tradicionais-uma boa opção para a proteção ambiental?-Beef Production in traditional silvopastoral systems-A second best for the environment? Revista Portuguesa de Ciências Veterinárias 109 1-10.

Vivas, E., Maia, R., 2008. Caracterização das Princiais Situações de Seca Histórica em Portugal Continental-A Importáncia da Utilização de Indicadores. Actas do $2^{\text {as }}$ Jornadas de Hidráulica, Recursos Hídricos e Ambiente, FEUP. Portugal.

Winkler, E., 2006. Recent trends in plant-ecological modelling: species dynamics in grassland systems. Prog. Bot. 67, 420-440. 